Araştırma Makalesi | Research Article

Doi: $10.18795 / \mathrm{ma} .03712$

\title{
Yavuz BAYRAM
}

Prof. Dr. | Prof. Dr. Ondokuz Mayıs Üniversitesi, Eğitim Fakültesi, Türk Dili ve Edebiyatı Eğitimi Bölümü, Samsun-Türkiye Ondokuz Mayıs Univ., Faculty of Education, Dep. of Turkish Language \& Literature Education, Samsun-Turkey yavuzebrar@gmail.com

\section{YÜZYILDAKİ BAZI DIVAN ŞAİRLERINNE GÖRE "ŞiïRDE GAYE"*}

\section{Özet}

Bütün şairler gibi, 16. yüzyıl divan şairlerinin de şiirle ilgili birçok gayesi vardı ve bu gayelerini genellikle kasidelerin fahriye bölümlerinde, gazellerin mahlas beyitlerinde ve divanların dibacelerinde dile getirmişlerdir. 16. yüzyıl divan şairleri için şiir, sevgiliye (güzel, devlet adamı, Allah...) ulaşmak için önemli bir "vasıta"dır. Çünkü şaire, aşkını dile getirme, sevgiliye yalvarma ve onun üstün niteliklerini anlatma firsatı verir.

Şiiri, sevgiliye yazılmış bir "arz-1 hâl"ya da bir "mektup" olarak düşünen bazı divan şairlerine göre eşe dosta, sevgiliye ve okurlara sunulabilecek en güzel hediye, şiirdir. Onlar aynı zamanda ölümsüzlüğe de șiirle ulaşabileceklerine inanmıșlardır. 16. yüzyılda "șiirde hakikat"i anlatmayı gaye edinmiș şairler, aynı zamanda şiiri, insanları ve sevgiliyi etkilemek amacıyla bir tür "büyü" ve "mucize" vasıtası gibi de kullanmışlardır.

Anahtar Kelimeler: 16. Yüzyll, Divan Şairleri, Şiir, Gaye.

\section{“OBJECTIVE ON POEM" ACCORDING TO SOME $16^{\text {th }}$ CENTURY DIVAN POETS}

\begin{abstract}
Like all poets, also Divan poets in the $16^{\text {th }}$ century had a lot of objectives related to poem and they expressed these objectives usually in the praise parts of eulogies, in the pen name couplet of gazels and preface of divans. According to $16^{\text {th }}$ century Divan poets, poem is means to arrive at beloved (beautiful, a statesman, God...). Because it gives an opportunity to a poet to express his love, to implore to beloved and to explain beloved's superior qualities.

According to some Divan poets who thought poem as a petition or a letter to beloved, poem is the most precious gift to friend, beloved and a reader. In the same time they believed that they reached immortality through poem. The poets in the 16th century who aimed poems to tell the reality in the same time used poem like a kind of sorcery and miracle to effect beloved and human beings.
\end{abstract}

Keywords: $16^{\text {th }}$ Century, Divan Poets, Poem, Objective.

\footnotetext{
Bu makale, 1995 yllında tamamlanan yüksek lisans tezimizin ilgili bölümünün güncellenip geliștirilmesiyle hazırlanmıștır. Yazıda taranmıș ve alıntı yapılmış olan on bir Türkçe divanın ait olduğu şairler şunlardır: Fuzûlî, Bâkî, Nev‘î, Hayâlî, Taşlıcalı Yahyâ, Muhibbî, Vasfî, Usûlî, Helâkî, Hayretî, Amrî.
} 
Harun Tolasa'nın işaret ettiği gibi, "Divan Edebiyatı, edebiyat tarihimizin başlangıcından günümüze kadar gerek zaman gerek edebî faaliyet bakımından en geniş ve yoğun bir devresidir. Fakat bu edebiyatımız hakkındaki bilgilerimiz, devrin uzunluğu ve edebî faaliyet açısından yoğunluğuyla hiç de mütenasip değildir. Hatta bu edebiyatımızın bazı konu ve dallarındaki bilgilerimiz yok denecek kadar azdır. Bu konu veya dallardan birisi de bu edebiyatımız üzerine kendi devrinde bir eleştirinin bulunup bulunmadığı bu eleştirinin niteliği, niceliği meselesidir.” (Tolasa 1982: 15-46)

Az olmakla birlikte, divan şairlerinin şiir, şair, eser ve okurla ilgili düşüncelerini irdelemeye yönelik olarak bugüne değin bazı çalışmalar yapılmıştır. Bu çalışmaların önemli bir bölümü, makalenin sonunda bir liste hâlinde verilmiştir. Söz konusu çalışmalar içinde ilk olması ve diğerlerine göre daha çok ayrıntı içermesi sebebiyle aşağıda Harun Tolasa'nın makalesinin ${ }^{1}$ sade bir planı çıkarılmıştır:

1. Eser

a. Konu

b. Mana, hayal, elfâz, eda, şive, sanat, mesel, nükte vb.

c. Şiir üzerine çeşitli tavsif ve takdirler

2. Yaratıcı (Şair)

a. Yaratıcı kişiliğin unsur ve kavramları

b. Yaratıcı üzerine genel tavsif ve takdirler

3. Çevre

Yedi alt başlıkta hazırlanan bu yazıda ise ilk olarak divan şairlerinin şiirden beklentileri ele alınmıştır. Şiiri hangi amaçlarla değerlendirdiklerini gösteren beyitlerin irdelenmesinden sonra, yine bununla bağlantılı olarak şiirin ebediyet duygusuyla, hakikatle, büyüyle ve mucizeyle ilgisine dair görüşlerin ortaya konduğu beyitler incelenmiştir. Yazı, divan şairlerinin "şiirdeki gaye”lerini özetleyen kısa bir değerlendirmeyle tamamlanmıştır.

\section{Şiirle Nereye?}

Her dönemde olduğu gibi, şüphesiz 16. yüzyılda da divan şairlerinin şiir açısından bir amacı, ulaşmak istedikleri hedefleri vardı. İşin güzel tarafi devrin hemen hemen tüm şairlerinde bu hedefin dile getirilmiş olmasıdır. Gayelerinin büyüklüğü ve ulviyeti nispetinde, şiirlerinin de kıymet kazandığını düşünen divan şairleri, şiir yoluyla sevgili

${ }^{1}$ TOLASA Harun, (1982), "Divan Şairlerinin Kendi Şiirleri Üzerine Düşünce ve Değerlendirmeleri”, Türk Dili ve Edebiyatı Araştırmaları Dergisi, İzmir: Ege Üniversitesi SBE Yayınları, s. 15-46. 
ya da memdûhlarına bir parça da olsa isteklerini anlatma, niyazda bulunma, aşklarını dile getirme imkânı bulurlar. Böylece sevgilinin ihsanına kavuşma ümidi taşıyan şairler, bir yandan da dillerinde sevgiliyi zikrederek daha bir yakınlı (kurbiyyet) kazanacaklarının bilincindedirler. İşte divan şairinin sanatla uğraşısını bu çerçevede değerlendirmek mümkündür. Bununla birlikte Amrî’nin aşağıdaki dizelerinde olduğu gibi, yârin şeker gibi tatlı söz söyleyen dudağı (la'l-i şeker-hâ) için şiir söyleyen şairler de vardır:

Hey ne şîînlik olur hûblar uydurmağ içün

Amrî şi'rin heves-i la'l-i şeker-h ${ }^{v}$ âlar ile

Amrî, G. 108-7

Muhibbî, şiir yoluyla pek çok güzele kavuştuğunu ve böylece şiirinin de büyük ve kârlı bir kazanç kapısı olduğunu düşünmektedir. Şiiri boş ve yersiz bir uğraş olarak görenlere de “İnsanı sevdiğine yakınlaştıran şiirin faydasız olduğunu kim iddia edebilir?" diyerek karşı çıkmaktadır:

Şi'r ile çünki Muhibbî nice dilber koculur

Bunu kim diyebilir şi'r ü gazelden ne gelir Muhibbî, G. 945-6

Muhibbî gibi şiiri sevgiliye kavuşma için bir vasıta olarak gören Nev‘î de şiir söylemesinin sebebini, sevgilinin huzuruna çıkıp elini öpme arzusu ile açıklamaktadır. $\mathrm{Bu}$ vesileyle bunca zarif ve hoş sözler, gerçek kıymetleriyle değerlendirilmiş, şair de sevgilinin huzuruna çıkmış olacaktır:

Bu şi ‘ri Nev`îyâ dildâr destine sunup da kim

El öpmektir garaz harc olmadan bunca zarâfetler

Nev`î, G. 159-5

Nev`î başka bir beytinde ise, sevgilinin dudağı imgesi eşliğinde, papağanı şekerin konuşturması gibi, kendisini de sevgilinin helvâ-yı vaadinin şiir söylemeye teşvik ettiğini belirtmektedir. Yani Nev`î, sevgilisinin vaadinin gerçekleşmesi için şiir söylemektedir:

Beni helvâ-yı va'din etti gûyâ

Getirir tûtîyi güftâra sükker

Nev`î, K. 20-31

Zaten Nev‘î̀’ye göre, sevgiliden söz etmeyen veya ona tesir etmeyen, kalbini yumuşatıp merhamete getirmeyen ve âşı̆̆ına acıması için vesile olmayan şiirin de hiçbir değeri kalmayacaktır. Demek ki şiir, sevgiliden söz etmeli, âşı̆̆ın hâlini sevgiliye arz edip merhamete gelmesine yardımcı olmalıdır: 
Etmezse ger halâvet-i nazmım sana eser

Nefsime ben de lokma-i şi 'ri edem harâm

Nev`î, K. 33-20

Vasfî’nin aşağıdaki düşünceleri de Nev‘î’ninkilerle uyuşmaktadır. Onun için de sevgiliye tesir etmeyen, onu duygulandırıp ilgisini çekmeyen şiirin bir anlamı yoktur. Nev`î, böyle şiiri nefsine haram ederken Vasfî, gerçek gayesine hizmet etmeyen şiirlerle dolu defterlerin ve divanın yanıp kül olmasının daya iyi olacağını söylemektedir:

Vasfiyâ şi'rin çün ol meh-rûya te'sîr eylemez

Oda yansın defter ü tûmâr u dîvânın senin Vasfî, G. 31-7

Vasfî için sevgilinin şiirlerine ilgi göstermesi, o kadar önemlidir ki, ünlü şairler Hâfız ve Selmân derecesine bile yükselse sevgilinin ilgisini çekmedikten sonra, bunun hiçbir anlamı olmayacaktır. Bütün insanların gözünde Hâfız ve Selmân kadar büyük bir ilgiye mazhar olan şairin asıl derdi, şiirlerinin öncelikle sevgili tarafından beğenilmesidir:

Vasfiyâ çünki şehin rağbeti yok fâyide ne

Tutalım nazm ile ben Hâfız u Selmân oldum

Vasfî, G. 48-6

Aşağıdaki dizelerden anlaşıldığına göre, Bâkî'nin çok daha mütevazı bir amacı vardır şiir söylerken. Onun tek isteği, sevgiliden söz eden hoş ve tatlı gazeller söyleyerek rakipleri kıskandırmak, gönüllerine bir kıskançlık elemi vermektir:

Vallahi gazel söylemeden çoktan usandik

Maksûd hemân hâside bir pâre ezâdır

Bâkî, G. 469-6

Taşlıcalı Yahyâ Bey, Muhibbî, Bâkî ve Nev'î’nin şiirden ortak bir beklentileri vardır: "Yâre arz-1 hâl eylemek" Amaçları, sevgilinin uğruna katlandıkları meşakkatlerin boşa gitmemesi, aşklarının ortada kalmamasıdır. Sevgili bunlardan hiç olmazsa haberdar olmalıdır. Haberdar olsun ki merhamete gelip de âşığına insaflı davransın. Aşağıdaki örneklerden de anlaşılacağı gibi, şairler hâllerini yâre arz ederlerken yine hadlerini bilirler ve sevgilinin karşısında nezaketi asla ihmal etmezler:

Mâ-hüve'l-maksûd olan şi'rimden ey Yahyâ

Hâlimi arz eylemektir yâre bâkî ve's-selâm Taşlıcalı Yahyâ, G. 248-5

Arz-1 hâl eyler Muhibbî dâ'imâ meh-rûlara

Gönderir her kişvere eş âr u dîvânı dürüst

Muhibbî, G. 186-5

Geh şi'r ü geh gazel deyü dildâre Bâkiyâ

Arz eyleriz nezâket ile hasb-1 hâlimiz

Bâkî, G. 573-5 
Bize Nev‘î gerekmez zümre-i kâlin hayâlâtı

Garaz şi'ri kişinin hasb-1 hâlin nâtık olmaktır

Nev'î, G. 86-5

Bundan başka divan şairleri, şiir yoluyla sevgiliye yakarışını, sadakatindeki samimiyeti anlatmak arzusundadırlar. Bâkî ile Helâkî'nin aşağıdaki beyitlerinde de görüleceği üzere, bu yolla sevgilinin gözüne girmeyi, affına ve himmetine kavuşmayı ümit etmektedirler:

Şi'r ü inşâdan murâdı âş1k-1 bî-çârenin

Arz-1 ihlâs eylemektir yâre Bâkî ve'd-du'â

Bâkî, G. 56-5

Lîkin garaz cenâbına arz-1 niyâzdır

İzin tozundan ettiği budur recâ nazar

Helâkî, K. 6-7

Divan şairlerinin şiirlerindeki ortak gayelerinden biri de yâre dua etmektir. Mesela Taşlıcalı Yahyâ Bey, sözün özünün yâre hayır duada bulunmak olduğu düşüncesindedir. Usûlî de Yahyâ Bey’le aynı gayenin peşindedir. Hem böylece âşık dostlarına da bir "Merhaba!" diyecek, belki de onların duygularına tercüman olacaktır:

Ömrün uzunluğuna hayr du'âdır maksûd

Leb-i dilber gibi el-kıssa sözün muhtasarı

Taşlıcalı Yahyâ, K. 7-42

Garaz bu şehlere bizden du'âdır

Irakdan âşıka bir merhabâdır

Usûlî, Yenice ŞEHR. 84

Vasfî'nin kaside söylemekten maksadı, şiirde sırf birtakım faziletli sözlerden bahsetmek değil, yalnızca sevgiliye dua etmektir. Vasfî’nin bu düşüncesi, 16. yüzyıl divan şairlerinin şiirden beklentilerini açık bir şekilde ortaya koymaktadır. Bu beklenti Vasfî'den alınan beytin ikincisinde "du'â-yı hayr etmek" ifadesi şeklinde dile getirilmiştir:

Kasîdeden garaz oldur ki ede şâha du'â

Degil durur bu ki şi‘riyle ede fazl izhâr

Vasfî, K. 1-40

Kasîdeden garaz ol kim du'â-yı hayrın edem

Dilimde gerçi ki dâyimdir ol du'â mezkûr

Vasfî, K. 5-27

Nev`î, şiirinde sevgiliyi överek onun lütfuna kavuşmayı ümit ederken; Fuzûlî, Müslüman Osmanlı şairine yakışır biçimde, gayet alçak gönüllü ve mütevekkilâne bir yaklaşımla, daha farklı bir yorumu gündeme getirmektedir. Ona göre, "Gül bile, elinden gelse o güzelin övgü bahçesinin bülbülü olurdu." Bu bakımdan şairin şiirde güzeller şahını övmesi hem çok doğal hem de şiirin güzelliği bakımından gereklidir: 
Umarın kim sana olan meddâh

Feyz-i lutfundan olsa ber-hurdâr

Nev`î, TRC. 6-54

K1l Fuzûlî medhin ol şâhın ki bâğ-1 medhinin

Bülbülü olurdu bulsa kuvvet-i güftâr gül

Fuzûlî, K. 9-58

Fuzûlî, şiirin varlık sebebini sevgilinin övgüsüne bağlamakta ve bu şartın eksikliği durumunda, şiirde hiçbir güzelliğin kalmayacağını savunmaktadır. Ona göre, sevgilinin güzelliğini anlatmayan şiirin estetik anlamda hiçbir değeri kalmayacaktır. Kaldı ki Usûlî’nin ifadesiyle, "Kalem (de) sevgilinin adını yazmayı öğrenir öğrenmez onun güzelliğiyle dolu bir mektup (şiir) yazmıştır.”:

Lahza lahza gülşen-i medhinde gûyâ olmasa

Bülbül-i nutku Fuzûlî’nin hôş-elhân olmasın

Fuzûlî, G. 235-7

Çün kalem adını imlâ eyledi

Nâme-i elemini inşâ eyledi

Usûlî, MİRACIYYYE-39

O hâlde hiçbir şairin, kalemini bu asli ve fitri işlevden alıkoymaya hakkı yoktur. Bu düşünce, Fuzûlî’nin yukarıda sözü edilen mütevekkil ve mütevazı yaklaşımıyla da örtüşmektedir. Zira Fuzûlî’ye göre şair, şiir söylemek, hele hele güzel şiir söylemek istiyorsa sevgiliden söz etmeli, onun vasıflarını anlatmalıdır. Bu itibarla sevgiliden söz etmek, şairin tasarrufunda olmadığından ortada bu yolla sevgiliye karşı yapılmış bir jest de yoktur. Olsa olsa sevgili, şiirine girmekle şaire karşı bir jestte bulunmuş olacaktır. İşte Fuzûlî ve Usûlî’nin hatta bütün divan şairlerinin şiirlerini güzelleştiren en önemli etken şiirde sevgiliyi anlatma arzusu olmuştur.

Taşlıcalı Yahyâ Bey, şiirin amacını biraz farklı yorumlayarak onu, firâk-1 yâr ile âvâre olan (âşığın) gönlünü yatıştırmak amacıyla kullanmaktadır. Yahyâ Bey’in avunmak için kullandığı şiiri Hayâlî Bey; şenlenmek, mutlu olmak için söylemektedir:

Yahyâ firâk-1 yâr ile âvâre olanın

Gönlünü egle bu gazel-i dilistânım al

Taşlıcalı Yahyâ, G. 237-7

Hayâlî nakşına bakıp güşâde olmağa dâ'im

Bu şi'rr-i nâzenînim defter ü dîvâna tapşırdım

Hayâlî, G. 362-5

\section{Şiir Mektup Mu?}

Divan şairlerinin, şiiri bir mektup olarak tanımlama fikri de diğer tanımlamaları gibi ilginçtir. Onlar için aşklarını dile getirmenin, hâllerini yâre arz etmenin bir yolu da yâre mektup yazmaktır. Divan şairleri, şiirlerini sevgiliye yazılmış bir mektup olarak 
değerlendirirlerken bunun karşılığında sevgiliden bir parça medet umarlar. Vasfî̀ de olduğu gibi, sevgilinin hiç olmazsa aşklarından haberdar olması da onlar için bir kazançtır:

Diledim derd-i dilimden sana bir nâme yazam

Doldu evrâkın içi kanlı yaşından kalemin

Vasfî, G. 30-4

Demek Vasfî’nin gönlü öylesine büyük bir aşk acısı çekmektedir ki, bundan bahsettiği mektup (şiir), kaleminin kanlı gözyaşlarıyla dolmuştur. Buna karşılık sevgilinin merhamete gelmesini ümit etmek de şairin en tabii hakkıdır. Diğer yandan Usûlî, şiiri, içindeki hasret ve ayrılık acısını anlatmak için söyler. Onun gözünde şiir, hasret ve ayrilık mektubudur:

Okurdu halka hasret nâmesini

Kara yazılı firkat nâmesini

Usûlî, Yenice ŞEHR. -55

Aşağıdaki beyitlerin ilkinde Taşlıcalı Yahyâ Bey, şiir için "mihnet nâmesi” ifadesini tercih ederek onu, sevgilinin kalbine sapladığı oklarla (kirpik) yazdığını bu nedenle içindeki yaralarının kızıl kanlarla dolduğunu söylemekte. İkinci beyitte ise Hayretî, bunun zorluğuna işaret etmek için, kalemi eline alır almaz gönlündeki elemlerin ağırlığıyla elem namesinin yazıldığı kâğıdın iki büklüm olduğuna ve kalemin kan ağlamaya başladığına işaret etmektedir:

Yazmak için hâme-i tîrinle mihnet nâmesin

Sürh ile zahmım devâtı pürdür ey kaşı kemân

Taşlıcalı Yahyâ, G. 381-4

Aldım elime tâ ki yazam nâme-i elem

İki büküldü kâğıd u kan ağladı kalem Hayretî, MUS. 19-I

Aşağıdaki beyitlerin ilkinde Taşlıcalı Yahyâ Bey, şiirini mektup olarak nitelendirmekte ve bu mektubun içinde hep sevgiliyi anlattığını kendine has üslubuyla da onu ilgi çekici kıldığını söylemektedir. Kaldı ki ikinci beyitte dikkat çeken Usûlî’nin ifadesiyle, kalem yazıyı söker sökmez ilk olarak sevgilinin güzelliğini anlatan bir mektup yazmıştır. Dolayısıyla şairin de bu anlamda başka bir seçeneği yok demektir:

Beyânı nâmemin mahbûb oluptur

Hayâl-i hâs ile mergûb oluptur

Taşlıcalı Yahyâ, İstanbul ŞEHR. -305

Çün kalem adını imlâ eyledi

Nâme-i hüsnünü inşâ eyledi

Usûlî, MIRACIYYY-39 


\section{En Güzel Hediye: Şiir}

Şiir, divan şairleri için sevgiliye sunulabilecek en güzel hediyedir. Muhibbî’nin aşağıdaki beyitlerinde dediği gibi, nasıl rind yaratılışlı insanlar sevgililerine kâğıt üzerinde şeker sunarlarsa şairler de sevgiliye tatlı ve hoş şiirlerini ithaf ederler. Muhibbî'nin bu tatlı ve hoş hediyesini alan dostlar onu takdir edip "Helâl olsun!" diyeceklerdir:

Tuhfe iletir şi' $r$-i şîrînin yine cânâneye

Rind olan mahbûbuna kâğız ile şeker sunar

Muhibbî, G. 430-5

Ey Muhibbî tuhfe gönder şi 'rini yârân için

Her birisi diyeler tahsîn ile sâbâşlar

Muhibbî, G. 956-8

Muhibbî'nin korkusu, hediyesinin sevgili tarafından kabul edilmeme ihtimalidir. Şair bu mütevazı hediyenin kabulü için sevgiliye yalvarmaktan da geri kalmaz:

Eyle gel şi'rr-i Muhibbî’yi kabûl

Gerçi kim bir tuhfedir illâ hakîr

Muhibbî, G. 429-5

Muhibbî, bu hoş hediyesini başkalarına da tavsiye etmektedir. Ona göre, Kum² ile Kâşân ${ }^{3}$ 'a gidecek her yolcunun o kutsal yerlere götürebileceği en güzel hediye şairin gazelidir. Kaldı ki Nev‘̂̂’nin dediği gibi, bir şairde aşkı ve şiirleri dışında, sevgiliye sunmaya layık başka nasıl bir hediye olabilir?

Ger yolun düşer ise varma tehî dest Acem'e

Bu Muhibbî gazelin Kum ile Kâşân’a ilet Muhibbî, G. 200-5

Suhandır sana lâyık bende tuhfe

Metâ‘-1 cân u dil nakd-i muhakkar

Nev`î, K. 20-29

\footnotetext{
${ }^{2}$ Kum: Irak ülkesinde bir vilayet adıdır. Kum mu'arrebidir. Hâlâ mu'arrebiyle meşhurdur. Gön ağacına da denir. Kesiren muharrefi ketre tabir olunan zamk ondan hasıl olur. Arabîde şeceretü'l-kuds, misvâkü’libâd ve misvâkü'l-mesih derler. Arabîde teşdid-i mimle esvab yani astin manasınadır (Mütercim Âsım Efendi, 2000).

${ }^{3}$ Kâş: Mâş vezninde edat-1 temennidir. Kâşki ve nolaydı manasınadır ki teessüf, dirig ve hasret mevkiinde irad olunur. Ah nolaydı ile tabir ederler. Kâşân muhaffefi olur ki Irak-1 Acem'de bir şehr-i meşhur adıdır (Mütercim Âsım Efendi, 2000).

Kâş: Kâşkî gibi temennî edatıdır. Teessüf mevkiinde de kullanılır. \& Kâşân muhaffefi olur. Kâşân, İran'ın ortasında vaktiyle iyi şişe ve şair, kıymetli kablar, tuğlalar yapılan, dokuma ve meyvesiyle meşhur bir şehir \& şişe (Şükün, 1996).
} 
Bâkî’ye göre şiirleri, güzellerin birbirlerine sunacakları kadar hoş hediyelikler iken; Muhibbî için şiir, bir hediye olmaktan başka, aynı zamanda sevgilinin anısına bir hatıra niteliğindedir:

Vasf-1 cemâl-i yâr ile Bâkî gazellerin

Biri birine sundu güzeller tuhâf gibi

Bâkî, G. 170-5

Sen bî-vefânın yâdına dedi Muhibbî bir gazel

Lahdinde ger gûş eyleye tahsîn ede Selmân ana

Muhibbî, G. 54-5

Nev`î de şiire, hatıra gözüyle bakmaktadır. Gönlünün derinliklerinden gelen ilhamla yazdığı şiirleri sayesinde, bir yandan zamana karşı adını yaşatabilmenin keyfini tadarken bir yandan da insaf sahibi eleştirmenlere hoş bir hatıra sunmaktadır:

Medhin güherlerin delip elmas-1 tab“ ile

Dizdim zamâne silkine bir nazm-1 yâdgâr

Nev`î, K. 13-41

Bâğ-1 tab'1mdan kopardım bu gül-i sad-bergi ben

Sundum insâf ehline bir yâdgâr-1 mu'teber Nev'î, K. 12-96

\section{4. Şiir-Ebediyet İlgisi}

Bütün sanatsal etkinliklerin özünde sanatçının, ardında kendinden daha uzun ömürlü bir eser bırakma arzusu yatar. Divan şairlerinin pek çoğu, şiirlerinde bu arzuyu dile getirmişlerdir. Mesela Hayâlî Bey aşağıdaki beytinde, kader belini bükmeden yani yaşlanıp elden ayaktan düşmeden (ölmeden) şiir bağına, sonsuza kadar dimdik ayakta kalacak bir servi diktiğini söylemektedir:

Ben ol Hayâlî’yim ki beni egmeden cihân

Diktim bu nazm bâğına bir yâdigâr serv

Hayâlî, K. 11-20

Hayâlî Bey'in aşağıdaki beyti, şairin ebediyet uğruna nelere katlanabileceğini göstermesi açısından dikkate şayandır. Beyitte gül suyu üretimiyle ilgili ayrıntılardan da yararlandığı anlaşılan şaire göre, nasıl gül, kendini mahvetme pahasına ardında güzel bir koku bıraktıysa kendisi de öldükten sonra, geride ebediyen yaşayacak hoş ve latif şiirler bırakmıştır:

Ben fenâ bulsam sözüm bâkîdir ey Cemşîd-fen

Kendi mahv oldu gül-âbından kodu âsâr gül Hayâlî, K. 12-23

Nev‘î de bunu başardığı için mutludur. Böylece artık bu dünyadan ayrılacağını aklına getirip üzülmesine de gerek kalmamıştır. Nitekim Husrev, Efrâsiyâb ve Sâm gibi ünlüler de bu yolla, adlarını günümüze kadar yaşatmamışlar mıdır? 
Ecel câmın içip gam çekme Nev`î telh-kâm olsan

Kodun bu meclis-i fânîde bir şîrîn suhan bâkî

Nev`î, G. 484-5

Âb-1 hayât-1 nazm iledir zinde-nâmlık

Zinde degül mi Husrev u Efrâsiyâb u Sâm

Nev`î, K. 33-17

Taşlıcalı Yahyâ Bey de şiir sayesinde adını ölümünden sonra da yaşattığını söylemektedir. Yahyâ Bey, ebediyeti yalnız kendisi için istemez. Cansız da olsa güzel bir şehrin de buna hakkı vardır ve şaire göre, bunun için de yine şiire başvurulmalıdır:

Adımız nazm ile ihyâ eyleriz Yahyâ gibi

Şevkimiz var matla'-1 hûrşîd-i eş'âr olmadan

Taşlıcalı Yahyâ, G. 356-5

Anın adına urdum söze bünyâd

Ola tâ haşr olunca hayr ile yâd

Taşlıcalı Yahyâ, Edirne ŞEHR. 70

Diğer yandan Taşlıcalı Yahyâ Bey’le Muhibbî, ölümlerinden sonra, şiirlerinin rahmetle anılmalarına vesile olacağını ümit etmektedirler:

Ümîd oldur ki sözüm bula rağbet

Diyeler lutf ile Yahyâ'ya rahmet

Taşlıcalı Yahyâ, İstanbul ŞEHR. 314

Kim bu şi'ri-i dil-pesendi ele alıp okuya

Rahmet anın cânına ki beni rahmetle ana

Muhibbî, H. 65-8

Her kim okursa işbu Muhibbî gazellerin

Rahmet ana ki rahmet ile bir du'â kıla

Muhibbî, G. 2372-5

Onca güzel şiir sayesinde, okuyanları tarafindan rahmetle anılmayı ümit etmeleri elbette onların hakkıdır. Ne var ki dünya, gelip geçici olmasının yanı sıra vefasızdır da ve Bâkî'nin mühründe yazdığg gibi, hakkıyla baki olan yalnızca Allah’tır. Ondan başka her şey fânidir: "Cihân fânidir, anda vefâ yoktur. Bâkî olan yalnız O'dur; O’ndan başka olan herşey fânîdir."

O hâlde şairin bu kubbede, ardında güzel hatıralar ve hoş bir sâdâ bırakmaktan başka yapabileceği bir şey yoktur. Yüzyıllardır dillerden düşmeyen şairin aşağıdaki dizeleri, bu anlamda gerçekten ilgi çekicidir:

Âvâzeyi bu âleme Dâvûd gibi sal

Bâkî kalan bu kubbede bir hôş sadâ imiş

Bâkî, G. 535-3 


\section{5. Şiir-Hakikat İlgisi}

Hakikat, 16. yüzyıl divan şairlerinin şiirdeki en önemli amaçlarından biridir. İlk bakışta paradoksal bir yaklaşım gibi görünse de 16. yüzyıl divan şairlerinin divanları incelendiğinde kendi duygu ve düşünce dünyalarına özgü bir şekilde, hakikate bağlı kaldıkları hatta bunu güzel şiirin gereği saydıkları görülecektir.

Divan şiirinde sevgilinin genelde Allah'ı temsil ettiğini biliyoruz. Daha önce de zaten divan şairlerinin şiiri sevgiliye ulaşabilmek için bir vasıta olarak gördüklerine işaret edilmişti (Bkz. Şiirle Nereye?). Sevgilisine hâlini arz edip niyazda bulunmak, ona dua etmek isteyen şair, ihlasla şiire sarılmaktadır. Divan şairlerinin hayata bakış açıları dikkate alınıp kullandıkları kelimelerin görünür anlamları değil de kastedildikleri anlamları esas alındığında karşımıza gerçekten çok değişik, şaşırtıcı sonuçlar çıkacaktır. Nitekim bu bölümün sonunda benzer bir sonuçla karşılaşılacaktır. Örneğin Muhibbî aşağıdaki beytinde, divan şiiri hakkında yaygın kanaatlere ${ }^{4}$ aykırı olarak şiirin gerçekten söz etmesi ve gerçeği okuyuculara tanıtması gerektiğini savunmaktadır:

Ey Muhibbî söyle söz versin hakîkatten haber

Şimdiki şâ‘irlerin her bir sözü zâhir geçer Muhibbî, G. 759-5

Hayâlî, şiirin bütün mecazi görünümü altında, gerçeği anlattığını söylediği bir beytinde, bu noktaya daha da dikkat çekmektedir. Ona göre insan aklı (akl-1 dûrbîn), şiirdeki bu inceliğin farkına varabilecek kadar keskin değildir:

Şi'rr oldur kim mecâz iken hakîkat bahşola

Ermedi bî-zevk ana illâ ki akl-1 dûrbîn Hayâlî, K. 23-34

\footnotetext{
${ }^{4}$ Örneğin Yaşar Nabi'nin poetik makalelerden oluşan küçük bir antoloji niteliğindeki "Şiir Sanatı" adlı kitabında yer alan bir yazısında Nurullah Ataç, daha sonra gerçeğin farkına varmakla birlikte, bir zamanlar divan şiirinin gerçekten uzaklığını dile getirmek için onun insani olmadığını söyleyecek kadar ileri gittiğini itiraf etmektedir: "Bir zamanlar Divan Edebiyatının insani olmadığını, bize insanoğlundan haber getirmediğini iddia etmiştim. Bunu söylerken ne kadar ileri gittiğimi, birtakım hazineleri görmemiş, bilmemiş gibi gözüktüğümü farketmiyor değildim. Zaten o iddiamın yanlışlığını ispat için kendim de Fuzûlî'den Gâlip'ten, daha başka şairlerimizden birçok beyitler söyleyebilirdim. Ahmet Hamdi Tanpınar bana, 'İnsanoğlunun uğraştı̆̆ herhangi bir işin insani olmaması nasıl kâbildir' diye sormuştu. Bu itirazı çok haklı idi. İddiamdan kendim de utandım" (Nayır 1958: 68).

$\mathrm{Bu}$ anlamda divan şiirine, Orhan Okay'ın "Sanat, dinleyen ve görende estetik bir zevk ve heyecan yaratan, gerçekliği sembolik olarak ifade eden eser ve hareketlerdir." tespiti açısından yaklaşmak önem kazanmaktadır (Okay 1990: 17).
} 
Onlar gerçeği üstadları Câmî' den öğrenmişler ve ünlü şair Hassan ${ }^{5}$ 'ın izinden yürüyerek şimdi de aynı şekilde, gerçeğin meşalesiyle yeni nesilleri aydınlatmaya devam etmektedirler. Diğer yandan Hayâlî, çağdaşı şairlerin düşüncelerine tercüman olarak şiirin beğenilip ilgi uyandırabilmesi için hakikat nüktelerinden söz etmesi gerektiğini ifade etmektedir:

Hayâlî tarz-1 eş‘ârın Hasan'dan şîve ögrenmiş

Hakîkat bâdesini câm-1 Câmî’den içensin sen Hayâlî, G. 411-5

Şi'rinde ey Hayâlî nikât-ı hakîkat an

Tâ dôstâna her biri bir dâstân ola

Hayâlî, G. 8-5

\section{6. Şiir-Büyü (Sihr, Efsûn, Tılısm) İlgisi}

Necip Fâzıl, Çile'de şairi bir tılsım ustası olarak tanımlar. ${ }^{6}$ Şiirin okuyucuda uyandırdığı hisler göz önüne getirildiğinde ona daha çok hak verilebilir. Prof. Dr. Mustafa Özbalcı'nın bir makalesinde (Özbalcı 1990: 221) vurguladığı gibi, "Biz şiirin büyülü aynasında biraz da kendimizi görürüz.” En azından şiirde bizden, bizim duygularımızdan bir şeyler de olsun isteriz. Şiirde kendimizden bir şeyler bulduğumuzda büyülenmiş gibi oluruz. Nitekim insanların çok büyük güzellikler karşısında "Büyülendim!, Hayran kaldım!" demeleri bundan olsa gerek. Sabahattin Eyüboğlu da Yaşar Nabi'nin Şiir Sanatı'na aldığı bir makalesinde şöyle der: "Bütün bunlar beni şiirle büyü arasında derin bir münasebet olduğu neticesine götürüyor. Büyünün yaptığı şey telkinlere müsait bir iklim yaratmaktır. Bu iklim olmadıkça büyücünün hareketleri, sözleri ve dekorları ne kadar boş ve zavallıdır” (Nayır 1958: 68).

Divan şairleri de "sihr, efsûn, tılsım, sâhir" gibi kelimeleri kullanarak şiirle büyü arasında ilişki kurmuşlardır. Şiiri tanımlarken sık sık bu kelimeleri kullanan divan şairlerine göre güzel şiir, sevgili ve okuyucuda uyandırdığı hayranlık duygusu ve ruhuna getirdiği coşkunlukla, etkisi açısından, gerçek bir büyüden farksızdır. Örneğin Nev`î ve Hayâlî aşağıdaki beyitlerde buna işaret etmektedirler:

\footnotetext{
${ }^{5}$ Hassan (Hassan bin Sabit), Peygamberimiz zamanında yaşamış bir şairdir. Peygamberimiz onun için mescide bir minber yaptırmıştı. Hassan (633-680) oraya çıkar müşrikleri yerip Peygamberimizi överdi. Peygamberimiz ona "Ruhulkuds (Cebraîl) sana yardım etsin!" diye duada bulunurmuş. Divan şairleri medhiyelerinde veya na'tlarda Peygamber'e övgü yazarken kendilerini sahâbe şâir Hassân b.Sâbit yerine koyar ve diğer bir vesîle ile ondan bahsedebilirlerdi (Pala 1989).

6 "Şair, ne yaptığının yanı sıra, niçin ve nasıl yaptığının ilmine muhtaç ve üstün marifetlerinin sırrına müştak bir tılsım ustası olacaktır” (Kısakürek 1987: 472).
} 
Ebyâtın ile eglenir oldu deli gönlüm

Turkurdu sözün sihr ile bir âb-1 revânı

Nev`î, G. 551-6

Meger Hayâlî sözünde tılısm-1 sihr ettin

Ki girdi koynuna yârin bu resme dîvânın

Hayâlî, G. 264-5

Mihrî Hatun da büyülü sözlerle sevgilisini kendine bağlamıştır. Kaldı ki onun gibi peri güzelliğindeki bir sevgilinin başka türlü yola gelmesine de imkân yoktur:

Sen perî-rûyu Muhibbî etti efsûn ile râm

Sihrdir benzer kelâmı meyli sen sâhirdedir

Muhibbî, G. 737-5

Hayâlî, sevgilinin dudağını övmede gösterdiği başarıyı, büyücülük yeteneğine bağlayarak aynı zamanda sevgilisini de yüceltmiş olmaktadır. Çünkü sevgilinin dudağı (şarâb-1 la‘l) o kadar tatlı o kadar güzeldir ki onu anlatabilmesi ancak şairin büyülü sözleri kullanarak söylediği renkli şiiri (nazm-1 rengîn) sayesinde mümkün olmuştur:

Nazm-1 rengînimle vasf ettim şarâb-1 la'lini

Sâhir-i nazmım anınçün ey gül efsûn eyledim

Hayâlî, G. 366-3

Aşağıdaki beyitlerde Amrî, "Şiirde sihir derecesinde güzellik arayan yanıma gelsin." diyerek herkese meydan okurken; Hayâlî şiirlerinin büyüleyici güzelliklerine işaret etmek amacıyla, yabani ceylan (gazâl-1 vahşî) imgesinden yararlanmaktadır. Hayâlî'nin şiirleri öylesine büyüleyicidir ki, yabani ceylanlar bile onları duyduklarında büyülenip oldukları yerde kalırlar. "Gazâl-1 vahş̂̂” terkibi ile sevgilinin nazına işaret eden şairin bu yabani ceylanı avlayabilmesi gerçekten ancak büyüyle mümkün olacaktır. İşte Hayâlî’nin sözleri (sihr ü efsûn) de büyücü sözleridir. Bunun için onları duyan her güzel, büyülerine kapılmaktan kurtulamaz:

Şehre Amrî geldigin din nükte-dân dilberlere

Yanına gelsin gazelde sihr ü efsûn isteyen $\quad$ Amrî, G. 77-7

Sihr eyledi Hayâlî gazel demede yine

Her bir gazâl-1 vahşî görüp anı râm olur

Hayâlî, G. 90-5

Muhibbî'nin sözleri de Hayâlî'ninkiler gibi büyüleyicidirler ve onun şiirlerini duyanlar, güzelliğine tutulacaklardır. Başka bir beytinde, şiir yoluyla peri gibi bir güzeli büyüleyen Muhibbî, böylece şiirin hiç de işe yaramaz, boş bir uğraş olmadığını göstermiştir:

Benzer Muhibbî sözleri sihr-i halâldir

Her kankı dilber işite anı da râm olur

Muhibbî, G. 720-5 
Şi'r ile ettin Muhibbî ol perî teshîrini

Deme şimdengirü sen eş‘âr u dîvândır abes

Muhibbî, G. 257-5

Taşlıcalı Yahyâ Bey, şiirini sevgilisine okuyanların aslında büyü yapmış olduklarını söylemektedir. Öyle ki kendini şiirin büyüsüne kaptıran güzel, hiç huyu ve alışkanlığ olmadığı hâlde, âşığının yanına gitmeye razı olmaktadır:

Beyt-i ahzânımıza gelmege efsûn eyler

Şi ‘r-i Yahyâ’yı şu kim okuya cânânemize

Taşlıcalı Yahyâ, G. 378-5

Nev`î, sevgilinin güzelliğini görmek isteyenlere, şiirin büyüsünü (efsûn-1 şi ${ }^{\top} r$ ) dillerine dolamalarını tavsiye etmektedir. Zira Nev‘̂̂’nin şiirinin her beyti, sevgilinin güzelliğini anlattığından okunduklarında her birinde sevgilinin güzelliğinin kerametleri (kerâmât-1 hüsn) görülecektir. Şairin şiirindeki büyü, sevgiliyi anlatımındaki ustalığından kaynaklanmaktadır:

Efsûn-1 şi ‘r-i Nev'î’ yi vird-i zebân edin

Dersen ola zuhûru kerâmât-1 hüsnünün

Nev`î, G. 271-6

Nev‘̂̂’nin şiir söyleyerek gerçekte yapmak istediği sevgilinin kalbini büyü yoluyla etkilemek ve merhamete getirmektir. Onun şiirleri, ruhunun coşkusunu, aşkının sıcaklığını taşıdığı için, sevgilinin gönlünü etkileyebilir ve onu heyecanlandırabilir:

Diler ki kalbini sihr ile eyleye teshîr

Dilinde sözleri cümle kelâm-1 rûhânî

Nev`î, K. 50-12

Muhibbî'nin şiiri, hem su gibi berrak (âb-dâr) hem de ateş gibi yakıcıdır (sûz-nâk). Şiirinin su gibi berrak olması, güzellik ve letafetiyle gönüllere ferahlık vermesinden, ateş gibi yakıcı olması da şairin aşk ateşini atlatmasından ileri gelir. İfade ettikleri anlamlar bakımından birbirlerine zıt olan bu iki kelime (âb-dâr, sûz-nâk), Muhibbî’nin şairlik gücünün bir nişanesi olarak şiirde bir araya gelmiş ve beytin anlamını güzelleştirmişlerdir. Muhibbî ayrıca, ateşle suyu bir arada tutmakla keramet gösterdiğini söylemektedir:

Âb-dâr eyler Muhibbî şi' rini hem sûz-nâk

Âteş ile âbı cem‘ etmiş kerâmet gösterir

Muhibbî, G. 892-5

Hayâlî’nin öylesine büyük ve etkili bir söylemi vardır ki, söylediği şiirlerin büyüsüyle, ünlü şair Selmân'ın ruhunu bile diriltebilmektedir:

Benem ol sâhir-i suhan-perdâz

Ki eyledim zinde rûh-1 Selmân'1

Hayâlî, K. 16-27 
Amrî’ye göre, güzellerle ahbablık ve aşinalık kurmanın en iyi yolu, şiirin büyüsünden yararlanmaktır. Size en küçük bir ilgi göstermeyen bir güzeli, şiirin büyüsüyle etkileyebilir ve kendinize bağlayabilirsiniz. Yok eğer canınız güzellerle aşina olmak istemiyorsa şiirden vazgeçmeniz bunun için yeterli olacaktır:

Amrîyâ efsûn-1 şi'ri okumaktan vazgel

İster isen hûblarla âşinâlıktan halâs

Amrî, G. 45-5

Görüldüğü gibi 16. yüzyıl divan şairleri, şiirle büyü arasında çok yakın bir ilgi kurmuşlardır. Konuyla bağlantılı olarak büyülemeye (teshîr etmek, sihr ü efsûn kılmak) yönelik oldukları anlaşılan Bâkî ve Muhibbî'den alınan aşağıdaki örneklerin de bu anlamda dikkat çekici oldukları görülmektedir:

Eger teshîr edem dersen cihânın her perî-rûyun

Oku eş 'âr-1 Bâkî’yi ki hep efsûn olmuştur

Bâkî, G. 508-5

Gerçi kıldım her gazelde nice bin sihr ü efsûn

Hûblar gûşuna almaz lîk bu efsânemiz

Muhibbî, G. 1174-5

\section{7. Şiir Mucize Midir?}

Divan şairlerine göre şiir, bir mucizedir ve bu nedenle de insanlar üzerinde etkilidir. Nitekim şairin İsa nefesli, şiirin de ölümsüzlük sembolü olması, şiirin mucizevi yönüyle ilgilidir. Nev‘î’nin “mu'cizevî kelâm”'yla ölüleri bile konuşturduğunu söylediği aşağıdaki dizeleri bu anlamda güzel ve somut bir örnek niteliğindedir:

Kelâm-1 mu'cizin izhâr edip nazm ehline gâhî

Dem-i cân-bahş ile Îsî sıfat mevtâyı söyletsen

Nev`î, G. 240-6

Taşlıcalı Yahyâ Bey, şiirini görenlerin, güzelliği karşısında duygularını "Mucize!" (i‘câz ${ }^{7}$ ) ve "Sihr-i halâl!" kelimeleriyle ifade edeceklerini söylemektedir:

Nazm u nesrini gören dedi zihî mîr-i kelâm

Biri i'câzdır anın birisi sihr-i halâl Taşlıcalı Yahyâ, K. 18-7

Nev‘î sözlerini, bazılarının apaçık büyü (mahz-1 efsûn-1 sâhir) olarak görmesine karşın, onların gerçek bir mucize olduklarını belirtmektedir. Böyle kimseler için "ağyâr" ve

\footnotetext{
7 İ'câz (a.i.c.: i'câzât): 1. âciz bırakma, acze düşürme 2. Şaşırtma 3. ed. mûcize sayılacak kadar düzgün söyleme 4. bir benzerini yapmada herkesi acze düşürme (Devellioğlu 2012: 468).

${ }^{8}$ Sihr-i helâl: "Bir beytin ilk mısra'ının sonunda yer alan kelime veya kelime grubunun, birinci mısra'ın sonuna bağlanabileceği gibi ikinci mısra'ın baş tarafına da bağlanabilecek nitelikte olmasıdır” (Külekçi 1995: 246). Sihr-i helâl (helâl olan büyücülük) : ed. Her iki tarafa bağlanması mümkün olan bir ara cümle veyâ kelimeyi muhtevî mısrâ veya beytin rûha hoş gelmesi hâli (Devellioğlu 2012: 1111).
} 
"erzâl-i zümer" tabirlerini kullanan şaire göre, bunlar daha baştan, şairi karalama niyetinde oldukları için, kaleminin ayı ikiye bölmesi hâlinde bile, Hz. Peygamber'e yaptıkları gibi, inkârlarında inat edecekler ve bu mucizeyi kaba bir söyleyiş (tağlîz-i hisse) diye geçiştirmeye kalkışacaklardır:

Sözüm mu'ciz-i nakddir gerçi ağyâr

Sayarlar anı mahz-1 efsûn-1 sâhir

Nev`î, K. 55-17

Göstere hâmem eger i'câz-1 "ve'n-şekka'l-kamer"

Haml eder tağlîz-i hisse anı erzâl-1 zümer

Nev`î, K. 12-94

Aşağıdaki dizelerinde benzer bir telmihi gündeme getiren Bâkî, mucizevi şiirine öylesine güvenmektedir ki, gelmiş geçmiş bütün büyücüler bir araya toplansalar şiirinin bir eşini daha söyleyemeyeceklerdir:

Hak budur Bâkî nazîr olmaz bu mu'ciz nazmına

Şi're âğâz etseler şimdengirü sehhârlar

Bâkî, G. 388-7

Muhibbî de şiirlerini inceleyenlerin, üslûbu için "lisân-1 gayb", sözleri için de "mu'ciznizâm" diyeceklerini ve bu meziyetlere sahip şiirinin yeni bir mucizeyle, Acem ülkesine ulaştığında büyük şair Selmân’ı kabrinde diriltebileceğini iddia etmektedir:

Derler Muhibbî şi'rine ol dem lisân-1 gayb

Mu'ciz-nizâm sözlerini ger rakam kıla

Muhibbî, G. 2557-5

Muhibbî mu'ciz-nazmın Acem iklîmine erse

Kılarsa zinde kabrinde aceb mi rûh-1 Selmân'1

Muhibbî, G. 2749-5

\section{SONUÇ VE DEĞERLENDİRME}

Bu değerlendirmeler 1şığında bazı 16. yüzyıl divan şairlerinin "şiirdeki gayelerine dair" görüşlerini aşağıdaki gibi özetlemek mümkündür:

Divan şairleri de günümüz şairleri gibi şiir, şair, eser ve okur gibi poetik olgu ve kavramlar üzerinde durmuşlar ve bunlarla ilgili düşüncelerini eserlerinde ortaya koymuşlardır.

Divan şairlerinin şiir, şair, eser ve okurla ilgili görüşlerine en çok gazellerin mahlas beyitleriyle, kasidelerin fahriye beyitlerinde ve divanların dibacelerinde rastlanır.

"Divan şiirinde poetika" üzerine yapılacak çalışmalarda, özellikle dikkate alınacak anahtar kelimeler (terimler) şunlar olmalıdır: şi ${ }^{\top} \mathrm{r}$, nazm, gazel, beyt, mısra', satr, sütûr, divan, fesahat, belagat, medh, name, san'at, ma'na, kaside, na't, matla', nazire, söz, 
kelam, suhan, zeban, lisan, güftar, lafz, nutk, nükte, güft ü gû, ta'bîr, terane, şâ‘ir, nazım, kalem, hâme, kilk, debîr, devât, bülbül, tûtî, suhan-gû, nâtık, ehl-i sanâyi`, gazelhân...

Şiir, insanı güzellere ve sevdiklerine (sevgili, Allah, Hz. Muhammed, din ve devlet büyükleri...) yakınlaştıran bir araçtır.

Güzel şiir, kıskanç ve art niyetli kimselere şairin vereceği iyi bir ders niteliğindedir.

Şiir, sevgiliyi övmek, ona dua etmek, arz-1 hâlde, arz-1 niyâzda ve arz-1 ihlâsta bulunmaktan ibarettir.

Şiir, sevgilisinden ayrı düşen ve onun aşkıyla yanan gönüller için bir teselli kaynağı, bir tür sığınaktır.

Şiir, âşı̆ğın yaralı ve dertli gönlündeki duygularını kanlı gözyaşlarıyla yazıp sevgilisine gönderdiği bir mektuptur.

Şiir, dostlara ve sevgiliye sunulabilecek en güzel hediyedir (tuhfe, tuhâf).

Şiir, şairin adının yaşaması ve şairin rahmetle anılmasını sağlar. Yani şiir, şair insan için bir ebediyet vesilesidir.

Şiir, anlayanlar için mecazi görünümü altında daima hakikat nüktelerinden haber verir.

Şiirin, güzelliğiyle sevgiliyi bile etkilemesi ve onu âşığına yakınlaştırması, şiirle büyü (sihr, efsûn, tılsım) arasında bir ilgi bulunduğuna işaret eder.

Okuyucuda hayranlık duygusu uyandırması açısından güzel şiir, aynı zamanda bir mucize niteliğindedir.

\section{DIVAN ŞIIIRINDE POETIKA EKSENLİ BAZI ÇALIŞMALAR}

AÇIKGÖZ Nâmık, (2000), "Klâsik Türk Şiiri Tenkid Terminolojisi ve 'Âb-dâr' Örneği”, Türk Kültürü İncelemeleri Dergisi, S. 2, s. 149-160.

AÇIKGÖZ Nâmık, (2006), “'Hayal'den 'İmge’ ye Klasik Türk Şiiri”, Türk Edebiyatı, S. 397, s. 8-9.

ŞENTÜRK Ahmet Atilla, (2007), "Klâsik Şiir Estetiği”, (Haz. Talât Sait HALMAN vd.), Türk Edebiyatı Tarihi I, s. 361-402, İstanbul: KTB Yayınları.

ANDREWS Walter G., (2006), "Osmanlı Şair Biyografileri (Tezkireler) ve Osmanlı Edebiyat Eleştirisi”, (Haz. Talât Sait HALMAN), Türk Edebiyatı Tarihi 2, s. 117-120, Ankara: KTB Yayınları. 
ARI Ahmet, (2005), "Şeyh Gâlib'in Poetikası”, Osmanlı Araştırmaları (The Journal of Ottoman Studies), C. XXVI, s. 51-72.

AVŞAR Ziya, (2001), "Divan Şiirinin Poetik Verilerine Yeni Bir Yaklaşım Denemesi”, Hece, Türk Şiiri Özel Sayısı (53-54-55), s. 323-330.

AVŞAR Ziya, (2007), "Şairlerin Görüp Unuttuğu Bir Rüya: Belâgat”, Turkish Studies, Tunca Kortantamer Özel Sayısı II, s. 161-184.

AYDEMİR Yaşar, (2000), “Bursalı İsmail Hakkı'nın Eserlerinden Hareketle Şiir Görüşü”, I. Uluslararası İsmail Hakkı Bursavî Sempozyumu Bildirileri, Bursa, 2627 Mayis 2000.

BAYRAM Yavuz, (2004), “16.Yüzyıl Divan Şiirinde 'Şiir, Söz ve Şair'le İlgili Anlam Alanları (Kelimeler ve Terkipler)", Selçuk Üniversitesi Türkiyat Araştırmaları Enstitüsü Türkiyat Araştırmaları Dergisi, S. 15, s. 53-64.

BAYRAM Yavuz, (2004), “16.Yüzyıldaki Bazı Divan Şairlerinin Şiiri Nitelemek Üzere Kullandıkları Sıfatlar", Türkbilig Türkoloji Araştırmaları, S. 2004/8, Ankara: Hacettepe Üniversitesi Edebiyat Fakültesi Türk Dili ve Edebiyatı Bölümü Yayınları, s. 36-53.

BAYRAM Yavuz, (2005), “16. Yüzyılda Bazı Divan Şairlerinin 'Şiire ve Okura Dair' Görüşleri”, Millî Eğitim Dergisi, S. 168, Ankara: MEB Yayınları, s. 79-106.

BAYRAM Yavuz, (2005), “16.Yüzyıldaki Bazı Divan Şairlerinin 'Şaire ve İlhâm'a Dair Görüşleri”, Türklük Bilimi Araştırmaları, S. 18, s. 31-68.

BİLKAN Ali Fuat, (1986), “Divan Edebiyatında Tenkid”, Millî Kültür, S. 54, s. 10-13.

COŞKUN Menderes, (2011), "Klasik Türk Şairinin Poetikası Üzerine”, Bilig, S. 56, s. 57-80.

ÇAPAN Pervin, (1993), 18. yy. Tezkirelerinde Edebiyat Araştırma ve Tenkidi, (Yayımlanmamış Doktora Tezi), Elazığ: Fırat Üniversitesi.

ÇAVUŞOĞLU Mehmed, (1999), “16. Yüzyılda Dîvan Edebiyat1-Dîvan Edebiyatında Şiir Kavramı”, (Haz. Mehmet KALPAKLI), Osmanlı Divan Şiiri Üzerine Metinler, s. 208-217, İstanbul: Yapı ve Kredi Yayınları.

ÇETINDAĞ Yusuf, (2005), "Biyografik Bilgi ve Şiir Eleştirisi Açısından 'Çehâr Makâle"”, Bilig, S. 34, s. 145-169. 
ÇETİNDAĞ Yusuf, (2002), "Eleştiri Terimleri Açısından Herat Mektebi Tezkirelerinin Anadolu Tezkirelerine Tesiri”, Bilig, S. 22, s. 109-131.

ÇETINDAĞ Yusuf, (2002), "Şiir Eleştirisi Açısından 'Devletşah Tezkiresi"”, Akademik Araştırmalar Dergisi, S.13, s. 187-201.

DOĞAN Muhammed Nur, (1996), “Fuzûlî’nin Poetikası”, İlmî Araştırmalar, İstanbul. ERKAL Abdulkadir, İLTERBERK Ahmet Bülent, (2009), Divan Şiiri Poetikası, Birleşik Yayıncılık: İstanbul.

GÜR Nagihan, (2009), Latîfî’nin Eleştirel Perspektifinden Osmanlı Divan Şiirinin Poetikası, (Yayımlanmamış Yüksek Lisans Tezi), Ankara: Bilkent Üniversitesi.

KAPLAN Mahmut, (2001), "Sebk-i Hindî Şairlerinden Fehim, İsmetî, Nâilî ve Neşâtî’nin Divanlarına Göre Şair ve Şiir Hakkındaki Görüşleri”, Hece, Türk Şiiri Özel Sayıs1 (53-54-55), İstanbul.

KAPLAN Mahmut, (2010), Baki Güzellik-Aşk-Şiir, Ankara: Öncü Kitap.

KILIÇ Filiz, (1998), XVII. Yüzyıl Tezkirelerinde Şair ve Eser Üzerine Değerlendirmeler, Ankara: Akçağ Yayınları.

KILIÇ Filiz, MACİT Muhsin, (1992), "Divan Edebiyatında Poetika Denemeleri Tezkire Önsözleri”, Yedi İklim, S.3, s. 28-33.

KILIÇ Mahmut Erol, (2009), Sûfî ve Şiir: Osmanlı Tasavvuf Şiirinin Poetikası, İstanbul: İnsanYayınları.

MENGİ Mine, (2000), "Divan Şiir Dilindeki Mana, Mazmun, Nükte Kelimeleri Üzerine Bir Değerlendirme”, Divan Şiiri Yazıları, Ankara: Akçağ Yayınları.

OKUYUCU Cihan, (2010), Divan Edebiyatı Estetiği, İstanbul: Kapı Yayınları.

SARAÇ M. A. Yekta, (2000), "Klâsik Türk Edebiyatında Manada Orijinallik Meselesi”, Journal of Turkish Studies, 24/I, s. 229-235.

SAZYEK Hakan, (2001), Şiir Üzerine Şiirler, İstanbul: Perşembe Kitapları.

TARLAN Ali Nihad, (1990), "Divân Edebiyatında San'at Telâkkisi”, Prof. Dr. Ali Nihad Tarlan'ın Makalelerinden Seçmeler, (Haz. Müjgan CUNBUR), S. 45, Ankara: AKM Yayını, s. 70-80. 
TOLASA Harun, (1982), "Divan Şairlerinin Kendi Şiirleri Üzerine Düşünce ve Değerlendirmeleri”, Türk Dili ve Edebiyatı Araştırmaları Dergisi, İzmir: Ege Üniversitesi SBE Yayınları, s. 15-46.

TOLASA Harun, (1999), “Klasik Edebiyatımızda Divan Önsöz (Dîbâce)leri; Lâmi’î Divanı Önsözü ve (Buna Göre) Divan Şiiri Sanat Görüşü”, Journal of Turkish Studies, S. 3, s. 385-402.

TOLASA Harun, (2002), Sehî, Latîfî ve Âşık Çelebi Tezkirelerine Göre. 16. Yüzyılda Edebiyat Araştırma ve Eleştirisi, Ankara: Akçağ Yayınları.

TÖKEL Dursun Ali, (2003), "Divan Edebiyatında Eleştiri”, Hece Eleştiri Özel Sayısı, S. 77-78-79, s. 15-47.

TUNÇ Semra, (2000), “Muhibbî Dîvânında Şiir ve Şair ile İlgili Değerlendirmeler", Selçuk Üniversitesi Türkiyat Araştırmaları Enstitüsü Türkiyat Araştırmaları Dergisi, S. 7, s. 265-283.

YILDIZ Sümeyye, (2012), “Osman Nevres'in Güzelliğe, Şiire ve Şaire Bakış1”, Sosyal Araştırmalar Dergisi, C. 5, S. 21, s. 240-248.

\section{ÖRNEK METINLERIN ALINDIKLARI DIVANLAR}

Amrî Divanı, Haz.: Mehmed ÇAVUŞOĞLU, IÜEF Yayınları, İstanbul 1970.

Bâkî Hayatı ve Şiirleri, Haz.: Saadettin Nüzhet ERGUN, Bozkurt Matbası, İstanbul 1935.

Fuzûlî Divanı, Haz.: Kenan AKYÜZ, Süheyl BEKEN, Sedit YÜKSEL, Müjgân CUNBUR, Akçă̆ Yayınları, Ankara 1990.

Hayâlî Divanı, Haz.: Ali Nihad TARLAN, Akçă̆ Yayınları, Ankara 1992.

Hayretî Divanı, Haz:: Mehmed ÇAVUŞOĞLU-M.Ali TANYERİ, IÜEF Yayınları, İstanbul 1981.

Helâkî Divanı, Haz.: Mehmed ÇAVUŞOĞLU, İ̈̈EF Yayınları, İstanbul 1982.

Muhibbî Divanı, Haz.: Coşkun AK, KTB Yayınları, Ankara 1987.

Nev`î Divanı, Haz.: Mertol TULUM-M. Ali TANYERİ, IÜEF Yayınları, İstanbul 1977.

Usûlî Divanı, Haz.: Mustafa İSEN, Akçağ Yayınları, Ankara 1990.

Vasfî Divanı, Haz.: Mehmed ÇAVUŞOĞLU, IÜEF Yayınları, İstanbul 1980. 
Taşlıcalı Yahyâ Bey Divanı, Haz.: Mehmed ÇAVUŞOĞLU, İÜEF Yayınları, İstanbul 1977.

\section{YARARLANILAN DİĞER KAYNAKLAR}

NAYIR Yaşar Nabi, (1958), Şiir Sanatı, İstanbul: Varlık Yayınları.

OKAY Orhan, (1990), Sanat ve Edebiyat Yazıları, İstanbul: Dergâh Yayınları.

PALA İskender, (1989), Ansiklopedik Dîvân Şiiri Sözlüğü, Ankara: Akçağ Yayınları.

KISAKÜREK Necip Fâzı1, (1987), Çile, İstanbul: B. D. Yayınları.

ÖZBALCI Mustafa, (1990), "Şiire ve Şaire Dair Bazı Notlar”, OMÜ Eğitim Fakültesi Dergisi, Samsun, S. 5, s. 217-227.

Mütercim Âsım Efendi, (2000), Burhân-ı Katı, (Haz. Mürsel ÖZTÜRK ve Derya ÖRS), Ankara: TDK Yayınları.

ŞÜKÛN Ziya, (1996), Ferheng-i Ziyâ, İstanbul: MEB Yayınları.

KÜLEKÇİ Numan, (1995), Edebi Sanatlar, Ankara: Akçağ Yayınları. 